\title{
Oktatáspolitikai irányváltás a Szovjetunióban: egy iskolareform anatómiája (1958)
}

\author{
SOMOGYVÁRI LAJOS
}

\begin{abstract}
Pannon Egyetem Tanárképző Központ
Az államszocialista berendezkedés közoktatást érintő legjelentősebb átalakítási kísérlete 1958-ban kezdődött meg a Szovjetunióban, majd az egész keleti blokkon végigsöpört, melyhez a mintát az írásomban bemutatott folyamat adta. A kísérlet a hatvanas évek közepére, végére megbukott, azóta sem született átfogó, kritikai megközelítése a témának - ez persze a szocialista pedagógia jelentős részére igaz. Az iskolareformként definiált változtatásokat a politechnika, a munkára nevelés és gyakorlati oktatás jelszavai határozták meg, napjainkban is releváns kérdéseket felvetve, mint például az általános- és szakképzés viszonya, a korszerú múveltség mibenléte, vagy iskola és élet kapcsolata.

Tanulmányom a szovjet döntéshozatali mechanizmus, a különböző érdekcsoportok artikulálódó igényeit elemzi, melyek egy szimulált, kontrollált nyilvánosság kontextusában jelentek meg. A Hruscsov által kezdeményezett új szakasz tudatosan vont be szakértőket a tervezésbe, előkészítésbe, mellyel megosztotta a felelősséget, felmérte és leszerelte a lehetséges ellenvetéseket, valamint „megdolgozta” a közvéleményt, lefordítva a gyakorlat nyelvére a tennivalókat. Az ideológia és a pártirányítás primátusa nem kérdőjeleződött meg, de a döntéshozatal módosult a sztálini időszakhoz képest. A változtatás igényének felmerülése azonban Sztálin utolsó éveihez köthető, ezért innen kell kezdeni az elemzést.
\end{abstract}

\section{VITÁK A SZOVJET ISKOLÁRÓL}

Az 1958-es szovjet iskolareformot hosszú vita előzte meg. Sztálin egyik utolsó írása (1952) vetette fel a húszas évek óta először az általános politechnikai oktatás bevezetésének szükségességét, mely egyaránt fontos volt a társadalom kulturális átneveléséhez és - a hivatásválasztás előbbre hozásával - a gazdasági erők fejlesztéséhez. Az ideológiai és gazdasági érdek legitimációja, a kettős hivatkozás a későbbi diskurzus lényegi ismertetőjegyévé vált. Kalmár Melinda 
magyar történész az ötvenes évek első felének rendszerátalakító tendenciájaként értékeli a szovjet fejleményeket: a tudományos-technikai forradalomhoz való adaptációs kényszer, majd az átalakuló kelet-nyugati kapcsolatok, a hruscsovi koegzisztencia és verseny mind-mind abba az irányba terelték a döntéshozókat, hogy változtassanak a technológia, a gazdaságszerkezet, az állami és pártirányítás, valamint az oktatás területein. Célkitúzéssé vált a versenyképesebb tudás, szakképzettebb munkaerő létrehozása, mely alkalmazkodni tud a megváltozott körülményekhez és hatékonyabban képes múködni. Kalmár szerint az új szakasz formálódása 1951-1952-ben kezdődött, mikor már olyan válságjelek mutatkoztak a keleti blokkon belül, ami elodázhatatlanná tette a rendszer módosítását ezt a folyamatot Sztálin 1953-ban bekövetkezett halála csak felgyorsította (2014. 69-89. о.).

A XIX. kongresszus foglalta először direktívákba a teendőket az oktatást illetően (1952), a megvalósítás azonban csak nagyon lassan haladt előre: alsó fokon bevezették a kézimunkát (I-IV. osztály), felsőfokon a múhelyekben és mezőgazdaságban végzett gyakorlati tevékenységet (V-VIII., illetve X. osztályig) - az új tantárgyak és tevékenységformák bevezetése 1956-ig húzódott (DeWitt, 1961. 9. o.). Az 1956-os XX. kongresszuson Hruscsov vádbeszédet tartott a szovjet iskolarendszer ellen: a diákokat az intézmények nem készítik fel a gyakorlati életre, a XIX. kongresszus irányvonala nem valósult meg (1956). A következő két év a szovjet neveléstudomány, a pedagógusok, a politikusok és a közgazdászok/gazdasági tervezők vitáival telt el; ideológiai, szakmai és népgazdasági érvek egyaránt szerepet kaptak az eltérő nézetek közti konfliktusokban. Többek között a Szovjetszkaja Pedagogika adott teret a vitának, az ideológiai szempontok (Marx és Lenin tanításainak értelmezése) mellett a pártirányítás kívánságai (a XX. kongresszus irányvonala), a pedagógiai igények (új tantervek, a termelés alapjai tantárgy bevezetése) és a gazdasági fejlődés (mezőgazdaság, gép-, vegyipar, energiatermelés) támasztotta követelmények egyaránt előfordultak a diskurzusban (Szkatkin, 1958).

Az új tantárgyak, a gyakorlati képzés bevezetése (kötelező nyári gyakorlat formájában) szükségszerűen túlterheléshez vezetett, amit a vizsgák eltörlésével próbált megoldani az oktatásirányítás (DeWitt, 1961. 10. o.) - ezzel viszont újra előtérbe került az általános képzés és a szakképzés egyensúlyának megbomlása, a középiskola funkcióiról, funkcióváltásáról szóló viták megszaporodása. A Szovjetunióban a 10 éves, egységes iskola volt a cél, ami a valóságban 7 illetve 8 osztályos intézményekben realizálódott, mivel hiányoztak az anyagi, személyi és infrastrukturális elképzelések az eredeti terv megvalósításához - a 10 osztályos iskolák végül csak a nagyvárosokban jöttek létre (a szovjet iskolatípusokhoz ld.: Kairov, 1963). Az egységes iskola koncepciójának alapja az oktatási rendszer egyenlősítő funkciójáról vallott elv volt: a különböző társadalmi háttérből érkező gyermekek egy múveltségi szintre hozása, ami a szocialista pedagógia esetében a munkás-paraszt származású fiatalok helyzetbe hozásáról szólt. A szovjet 
egységes iskola integratív szándéka, a kollektív nevelés nem állt távol a nyugati tendenciáktól: az USA egységes iskolái külsőre hasonlóak ehhez a rendszerhez, illetve a komprehenzív iskolák feltúnése is analóg jelenség a hatvanas évek skandináv államaiban. A középfokú képzés minél teljesebb kiterjesztése szintén közös célként tételeződött a különböző iskolarendszerekben (az USA és a SZU iskolarendszerének összehasonlítása: Mitter, 1981; az egységes középiskola megteremtésének kísérletéről: Setényi, 1992; ennek elméleti alapja: Szebenyi, 1997).

Az egységes iskola elképzelésével szemben már 1956-ban felmerült a hosszabb távú gazdasági célokat szolgáló, pedagógiai szempontokkal is alátámasztható furkáció bevezetésének igénye. Ez azt jelentette, hogy az egységes közös képzés idejét lerövidítik és a diákokat már korábban a szakma/hivatás választásának eldöntésére késztetik - az így meghozott választás alapján a továbbiakban elválnak a képzési utak és különböző speciális képzési formákban részesülnek a tanulók. A leningrádi oktatási szakemberek által képviselt, a Literaturnaja Gazetában megjelent cikk ezt az irányvonalat képviselte 1956 decemberében és a Neveléstudományi Akadémia is ebben a formában foglalt állást a reformokat illetően 1957 elején. Az első 8 év után három irány közül választhattak volna a fiatalok: a fizikai, matematikai, technikai orientáció az ipari képzés céljait szolgálta, a biológiai a mezőgazdasági termelés felé vezetett, míg a humán változat a szolgáltatások, a leendő értelmiség tagjainak utánpótlását biztosította (a cikk és az Akadémia álláspontjához: DeWitt, 1961, 11-12, az Akadémia 1957-es, 1958-as szerepéről: Medlin, 1958).

Az 1956-1957-as tanévben már 585 iskolai kísérlet folyt az OSZSZSZK-ban a politechnika bevezetéséről, miközben az Akadémia az új óra- és tanterveken dolgozott. Az első négy osztályban kézimunka-tanítás folyt, ötödik és nyolcadik között múhelygyakorlatok, az utolsó három évben új tantárgyként bevezették az Ipari és mezőgazdasági termelés alapjai címú tantárgyat (Faragó, 1958). A tanmúhelyekben végzett gyakorlatot az órarenden kívüli, őszi és tavaszi munkákban való részvétel egészítette ki, a mi felső tagozatunknak megfelelő iskolafoktól, vagyis az ötödik osztálytól kezdve (Szovjetunió ..., 1958). Az elért eredmények alapján a kísérleteket összefoglaló 50 kutató lehetségesnek (de nem szükséges elemnek) tartotta egy szakma elsajátítását normál középiskolai oktatás keretében, ugyanakkor a túlterhelés problémája továbbra sem szû́nt meg (Ábent, 1958a). Az átalakítás előkészítésében és lefolytatásában nagy szerepet játszott a propaganda, ennek érdekében 1957 januárjától új folyóiratot indított az OSZSZSZK Közoktatásügyi Minisztériuma, Politechnicseszkoe Obucsenyije (Politechnikai Képzés) címmel (Faragó, 1957). A kérdés már csak az általános és szakmai képzettség egyidejú megszerzéséhez vezető út volt: a Minisztérium 1958 tavaszán a diverzifikált középfokot hagyta jóvá, amely az általánosan képző iskolák esetében a munkára nevelést több irányt is megalapozó szakmai előképzésként, jobb esetben szakképzésként fogta fel, emellett pedig meghagyta volna a korábbi szakképzési 
formákat. Azonban nem a furkáció intézményesült, hanem a gyorsabb megtérülést ígérő, közvetlen szakképzés (egy-egy szakmára való specializálódás) valósult meg a nyolcadik osztály után - azaz megmaradt az ideológiailag is fontos egységes (és egyenlősítő) iskola, a munkára nevelés formái pedig az aktuális és helyi, konkrét igényeknek megfelelően alakultak ki. A munkára nevelés irányvonalát végül a pártvezetés fellépése, egyéb érdekcsoportok igényei és a változó geopolitikai konstelláció alakította ki.

A kelet-nyugati kulturális kapcsolatok megélénkültek az ötvenes évek végén (párhuzamosan az ûrversennyel) - a szovjet oktatást átalakító kezdeményezések valójában világméretú tendenciákba illeszkedtek, ahogyan azt már korábban is láthattuk. 1958 áprilisában az UNESCO konferenciát tartott Sèvres-ben, ahol a középiskolai képzés aktuális kérdéseiről volt szó: a tankötelezettség felemelése, a korszerú múveltség tartalma, az általános és szakképzés viszonya a szovjet diskurzusban is gyakran előforduló témák voltak. Ebben az internacionális környezetben a szovjet küldöttség beszámolója nagy érdeklődésre tartott számot, hiszen a svéd és francia iskolareformokat is hasonló motívumok vezették ebben az időben (Jóború, 1958, 1961. 3-6. o.; UNESCOa, 1958). A XXI. Nemzetközi Nevelésügyi Konferencia előadói szintén a fejlődés új követelményeit akarták összhangba hozni az oktatási szerkezettel, a Szovjetunió és a szocialista országok a politechnika bevezetésével vélték ezt megoldhatónak (Csoma, 1958; UNESCOb, 1958). Nem tudjuk, hogy mekkora hatással lehetett a nyugati, haladónak nevezett pedagógiai irányzatok kezdődő recepciója a szovjet döntéshozatalra, ${ }^{1}$ majd a keleti blokkban beinduló folyamatokra, de úgy tûnik egy újabb területe nyílt a nyugati és keleti blokk közti versenynek.

A sèvres-i UNESCO konferencia időpontjában Hruscsov Magyarországra látogatott: a gesztus a konszolidálódó kádári rendszer támogató megerősítéseként volt értékelhető, mely hazánkat újra és végleg betagolta a szocialista országok táborába. A látogatás egyik fontos állomása volt a szovjet pártvezér Akadémián mondott ünnepi beszéde április 9-én. Hruscsov igyekezett megnyerni a magyar értelmiség színe-javát, kiemelte a múvelődés fontosságát „a különböző rendszerek békés versenyében" és meghirdette a közoktatás meginduló felülvizsgálatát - „új Szputnyik lesz a közép- és felsőfokú oktatás tervezett megreformálása” (Feljegyzés..., 1958). A békés egymás mellett élés, az enyhülés és a verseny, a feszültség kiéleződésének jelszavai egyébként gyakran váltogatták egymást az ötvenes évek végén, az aktuális geopolitikai igényeknek megfelelően, ami megnehezíti a korabeli források értelmezését.

\footnotetext{
191959-ben például a Voproszi Filozofii (A Filozófia Kérdései) címú szovjet folyóiratban ismertették az amerikai Viktor Perlo tanulmányát a tudományos-múszaki forradalomról (Simon, 1960). Igaz, Perlo az USA Kommunista Pártjának egyik vezetője és marxista közgazdász volt, de korábban elképzelhetetlen lett volna, hogy hasonló nyilvánosságot és elismerést kapjon egy nyugati tudományos cikk. Az oktatás átalakításának kelet-nyugati összehasonlításáról hasonló cikkek jelentek meg ebben az időszakban (Bori és Tihanyi, 1957).
} 


\section{HRUSCSOV FELLÉPÉSE}

A reformként definiált változtatások egy másik beszéddel kezdődtek - 1958. április 18-án Hruscsov a Komszomol XIII. kongresszusán tartott nagyhatású referátumot. A megszólalás újra az iskolák elleni vádbeszédként hatott: a pártvezér szerint alapvető hiányosság, hogy az iskola el van választva az élettól és a termeléstől, nem készít fel a társadalmilag hasznos munkára és a gyakorlati életre. Ezzel együtt jár a morális nevelés elhanyagolása, a fizikai munka lebecsülése („,Az iskolákban még nem eléggé oltják bele a gyermekekbe a munka megbecsülését...") és a felsőoktatásba való bejutás túlhangsúlyozása. A fiatalok vonakodnak a végzés után munkát vállalni gyárban vagy gazdaságban, amit csak felerősít a szülők negatív hozzáállása a kérdéshez: aki nem tanul jól, az munkás lesz. Ennek ellensúlyozására az SZKP főtitkára szerint a főiskolai felvételiknél is előnyben kell részesíteni azokat, akiknek van munkatapasztalatuk, ösztönözni kell a már dolgozókat a továbbtanulásra, minimum a középfok megszerzésére („Minden fiatal munkásnak tanulni kell..."), valamint elengedhetetlen a felsőoktatás társadalmi összetételének javítása (Hruscsov, 1958a). Mindezek miatt radikális változtatásokra van szükség az oktatásban. A szovjet pártvezető itt már a termelómunkára való általános felkészítésről, mindenoldalú fejlesztésról beszél, ami kimondatlanul is szemben áll a specializációval. Mindig figyelembe kell azonban venni, hogy a politikai vezetés csak általános irányelveket bocsátott ki, a megvalósítás ettől teljesen eltérhetett, jelen esetben is megvolt a kiskapu, a különböző termeloágak irányába való iskolai elágazások koncepciójának ismertetésével (DeWitt, 1961. 13. o.). A fó jelszó ettől fogva oktatás és termelőmunka összekapcsolása, az iskola és élet kapcsolatának megerôsítése.

Hruscsov szerint a gyakorlati képzésben részt vevő tanulók a kommunista társadalom aktív felépítőivé válnak majd, az oktatási fordulatot az erkölcsi érvek mellett közgazdasági indokok is alátámasztják (Coumel, 2009. 67. o.). Ez utóbbi szempontot az 1959 elején meghirdetett 7 éves terv csak erősítette: az 1959 és 1965 közötti időszakra előirányzott tervszámok az USA gazdasági utolérésének nagy ívú programját hirdették meg (az egy főre jutó GDP-ben, 1970-ig), ehhez viszont pótlólagos munkaerőre volt szükség - a diákok jelenthették volna a hiányzó humán erőforrás egy részét. A Komszomol-beszéd a felzárkózás egy másik aspektusaként a tudományos-technikai fejlődéshez szükséges általános múveltség megemelésének igényét szintén meghirdette, ami a középfokú végzettség kiterjesztésének célkitúzését jelentette az egész népességre: „Amikor munkásainknak és kolhozparasztjainknak középfokú általános múveltségük lesz, munkájuk majd egyre termelékenyebbé fog válni, és a munka termelékenységének szakadatlan növelése jelenti éppen végső soron a kommunizmus sikeres felépítésének legfóbb feltételét." (A beszédet idézi: Nagy, 1958. 807. o.) A marxista elmélet szerint e folyamatban a fizikai és szellemi munka közti különbség elóbb-utóbb eltúnik, a bérek közti különbség csökken, vagyis megvalósul 
a kommunista utópia. Ehhez a technikai fejlődés nyújt majd segítséget, hiszen a távirányítás, az elektrotechnika és az automatizálás bevezetésének hatása a munkaidő csökkentése lesz, ezen rendszerek múködtetéséhez azonban értelemszerúen magasabb fokú szakképzettség szükséges (Osztrotyitanov, 1958). Ez a folyamat csak úgy válhatott teljessé, ha a nappali tagozat mellett az esti, levelező képzési formákat, illetve a dolgozók iskoláihoz hasonló intézménytípusokat továbbra is extenzív módon növelik, ami viszont együtt járhatott a megszerzett képzettség színvonalának csökkenésével - jóllehet az eredeti cél éppen a szakképzettségi szint emelése volt.

Az akadémiai szféra képviselőinek többsége ezzel szemben még mindig ragaszkodott a furkáció koncepciójához, habár a kérdés már eldőlt: Goncsarov a Szovjetunióba látogató Nagy Sándornak, a Pedagógiai Tudományos Intézet igazgatójának még 1958 májusában is az általános múveltség megalapozásában, a politechnikai képzésben és egy speciális munkaterületen való elmélyedésben határozta meg az új középiskola feladatait (Nagy, 1958. 808. o.). Ebben az időszakban megszaporodtak a nyugati látogatások is a Szovjetunióban, ezek a beszámolók szintén megerôsítik a politikai-gazdasági szféra és az akadémiaiszakmai világ ellentétét (ld. pl.: Rudman, 1959). ${ }^{2}$

Zelenko, a Munkaerőtartalékok Hivatalának szovjet vezetője a gazdasági tervezés véleményét több cikkben ismertette 1958 nyarán (a Pravdában megjelent írások összefoglalásához ld.: DeWitt, 1961. 14. o.; Rudman, 1959. 254. o.). A 7 éves terv előkészítéseként Zelenko a szakképzett, betanított munkások kívánatos arányát jelölte ki, melyben az oktatás szerepét a szakképzésre és a munkaerő-tartalékok „kitermelésére” redukálta. A továbbtanulást a különösen tehetségesek számára tartotta volna csak fenn a hivatalvezető, a tervezet szerint a fiatalok többsége 15 évesen kerül majd a munkaerópiacra, ezzel feladva a 10 éves egységes iskola ideálját. Az új kötelező, általános politechnikai iskola 8 osztályos lett, ezzel párhuzamosan az esti/ levelező képzések számát megnövelték, hogy a dolgozók a munka megszakítása nélkül teljesítsék az egész lakosságra kiterjedő középfokú végzettség célkitûzését. A reformot tehát a világszerte meginduló oktatási expanzió határozta meg, amit igyekeztek összhangba hozni a politechnika követelményeivel és a gazdaság igényeivel (Kálmán, 1958), ami természetesen sokszor vezetett összeütközésekhez a különböző szereplők között.

Ugyanezen a nyáron Hruscsov is elkészítette tervezetét az oktatási reformról, ami a Pravdában jelent meg 1958. szeptember 21-én - a dokumentumot legtöbbször Tézisek néven emlegették. A vita ezután kikerült a nyilvánosság terébe, ahol felülről irányított és ellenőrzött „társadalmi vita” kezdődött az

${ }^{2}$ Az amerikai-szovjet rivalizálás a Szputnyik-sokk után az oktatás területére is kiterjedt, az általam elérhető beszámolók a szovjet iskolareformot általában pozitívan szemlélték (Lilge, 1959; Ross, 1960; Holmes, Read és Voskresenskaya, 1995. 19. o.). Ennek több oka is lehet: valószínúleg baloldali érzelmú amerikai pedagógusok és újságírók látogattak el a Szovjetunióba, illetve a mccarthyzmus természetes visszahatásának is tekinthető a szovjet törekvések irányában megnyilvánuló szimpátia. 
irányelvekről. 1958 őszén az SZKP KB és a Minisztertanács is jóváhagyta az iratot, ami így az év végén törvényerőre emelkedhetett.

\section{A TÉZISEK}

A Hruscsov-memorandum címe szinte teljesen megegyezett a később elfogadott törvény elnevezésével: Az iskola és az élet kapcsolatának megszilárditásáról és a közoktatási rendszer továbbfejlesztéséről. ${ }^{3}$ A dokumentum lerövidített változatát közölte a Népszabadság (1958), illetve a magyar közéleti-pedagógiai sajtóban is hamarosan megjelent a Tézisek ismertetése (Hruscsov, 1958b; Ábent, 1958b) - a szöveg elemzése e három forrás felhasználásával készült. Hruscsov tételmondata szerint a szovjet iskola nem oldja meg az ifjúság életre való felkészítését, csak a továbbtanulást segíti elő (a Komszomol-beszéd felütése ugyanez volt). A reform indoklása jelezte, hogy melyik érdekcsoport igényei érvényesültek: az oktatás a nemzetgazdaság fejlődése szempontjából fontos, fel kell használnia a technológia és a tudomány új eredményeit. A mennyiségi eredmények ellenére (írásbeliség elterjedése) számos probléma maradt, a legfőbb gondot az iskola elszakadása jelentette az élettől, mivel az oktatási rendszer túlságosan támaszkodott a forradalom előtti gimnázium hagyományához, ami a diplomához szükséges akadémiai, absztrakt tudást adja meg csupán, de semmi köze nincs a termeléshez. Ennek oka az volt, hogy a szovjet rendszer első időszakában más volt még a prioritás, a felsőoktatást kellett feltölteni munkás-paraszt származású fiatalokkal. A lenini alapelvekhez való visszatérés jegyében (amire Hruscsov sokszor hivatkozott, hogy elhatárolja magát a sztálinista politikától) mindenoldalúan fejlett, a gyakorlati életben gyökerező személyiség kialakítása szükséges. Az ideális személyiségnek a következő két fontos jellemzője van: jól ismeri a tudományok alapjait (itt főleg a természettudományokról, illetve a tudományos-technikai forradalom keltette új kihívásokról van szó); illetve a fizikai munkavégzésre késznek kell lennie.

A célul kitûzött, 10 osztályos, egységes oktatást két részre osztotta a tervezet: az első 7-8 év az általános képzésé (de az első szakasz utolsó két évében is szükséges már bekapcsolni a tanulókat a kolhozok és vállalatok társadalmilag hasznos munkájába), az utolsó 2-3 év a szakképesítés megszerzésének időszaka, külön városi (ipari) és falusi (mezőgazdasági) változattal. A tankötelezettséget hétről nyolc évre emelték, ezt hívták a középfokú oktatás első szakaszának, vagy más néven „politechnikai, nem teljes középfokú munkaiskolának”. A második szakasz a teljes középfokú végzettség megszerzésének időszaka, többféle iskolatípus tartozik ide: politechnikai középiskola, technikum, munkás-, falusi ifjúság iskolái, a különleges tehetségú gyerekeknek külön múvészeti és természettudo-

\footnotetext{
${ }^{3}$ A később ismertetendő törvény így hangzott: Az iskola és az élet kapcsolatának megszilárdításáról és a Szovjetunió közoktatási rendszerének továbbfejlesztéséről. A szöveg egyébként számos ponton emlékeztet a Komszomol-beszédre.
} 
mányos (matematika, fizika, kémia, biológia) jellegú iskola. Külön kiemelték az általános középfok megszerzésének feltételét, amit a kommunizmus építésének feltételéül szabott a vezetés: „minden munkás és munkásnő, minden kolhozdolgozó - férfi és nő egyaránt - középiskolát végezzen...". A gyakorlati órák száma első és negyedik osztály között heti egy óra, ötödik osztálytól heti két óra lett. Nyolcadik után mezőgazdasági gépészeti és elektrotechnikai változatot alakítottak ki (Zibolen, 1958. 203. o.).

Nemcsak a középfokot, az egész iskolarendszert érintette a változás, ennek megfelelően a továbbtanulás új útjait vázolták fel a tézisek. A fő irány a termelőmunkában való részvétel és a tanulás egyidejú biztosítása volt, esti/levelező képzések számának növelésével, osztott tanítással, a felvételiknél kedvezmények biztosításával a munkás-paraszt fiataloknak. A felsőoktatást is közelebb vitték volna a munka világához, az első 2-3 évben még a termelőmunka mellett képzelte el Hruscsov az oktatást („nem szabad a diákokat elszakítani a termeléstől”), a harmadik évtől fokozatosan felmentést kaptak volna a hallgatók ez alól, az utolsó két év pedig csak a tanulásról szólt az eredeti tervek szerint. Később ezt a részt érintette a legtöbb kritika, így át is alakították a felsőoktatásra vonatkozó fejezetet. A javaslat külön kiemelte a mérnökképzés fontosságát és azokat a területeket, ahol ez jelentőségteli lesz a következó évtizedekben: az atomenergia, automatika, elektronika, rádiótechnika, villamosgép- és múszergyártás, hírközlés, valamint a kemizálás tartozott ide. A természettudományok mellett a társadalomtudományok (a marxizmus-leninizmus) szerepét is hangsúlyozta az irat, mivel a világnézeti tudatosságot minden szakember számára alapvetőnek gondolták.

\section{REFORM A NYILVÁNOSSÁG TERÉBEN}

A tervezett intézkedések - a termelési gyakorlat bevezetése a középfok utolsó kettő és a felsőfok első két évében, az esti/levelező oktatás kiterjesztése, a különlegesen tehetséges tanulóknak létesített speciális tudományos és múvészeti (előkészítő) iskolák - a felsőoktatásba bejutás keresztmetszetét szúkítve, a népgazdasági ágak felé terelte a tanulók többségét. Az irat nemzeti vitára hívott fel, amely szervezett és ellenőrzött formában a sajtóban történt meg, továbbá rengeteg találkozót, előadást is szerveztek a helyi pártbizottságok. Kairov túlzónak túnó adatai szerint (1963) a nyilvános társadalmi vita során 299000 találkozó volt az Ukrán és az Orosz SZSZSZK-ban, melyeken 23 millió ember és 1300000 előadó vett részt 1958 decemberéig; a Pravda helyettes főszerkesztője, Gorjunov 14000 dolgozói levélról számolt be, ami a lapjához befutott a témával kapcsolatban (1959). A szimulált és kontrollált nyilvánosság, a különböző társadalmi-politikai és gazdasági érdekcsoportok igényeinek feltérképézése és korlátozott megjelenítése a Hruscsov által bevezetett új szakasz lényegi ismérve volt, ami együttjárt a szakmaiság bizonyos fokú érvényesülésével, szakértők 
bevonásával a döntéshozatal folyamatába (Kalmár, 2014. 104-105. o.) - az ő feladatuk elsősorban a már meghozott irányelvek legitimálása, konkretizálása volt.

Ebben az esetben a támogató hangok (Kairov, a Neveléstudományi Akadémia elnöke, Afanaszenko közoktatásügyi és Jeljutyin felsőoktatási miniszter) mellett kritikusabb hangok is megszólaltak: a tudományos élet képviselői főleg az általános múveltséget megalapozó szakaszt féltették, nem véletlen, hogy a novemberben újból előterjesztett és lerövidített tézis már kihagyta a felsőoktatás első két évének előírását a termelési gyakorlatról (Coumel, 2009. 69. o.). A diskurzusban természetesen a pozitív hangok domináltak (Megkezdődött a vita ..., 1958; Gorjunov, 1959), a kísérletek jó tapasztalatait és a „hatalmas népi mozgalom" erejét hangoztatták, ami a tézisek megjelenését követte. Kérdés persze, hogy valójában mennyire volt valódi a vita, hiszen a lehetséges kifogások feltérképezéseként is szolgálhatott a megindult nyilvános eszmecsere, hogy egyes elemek visszavonásával a vezetés megmutassa kompromisszumkészségét. Mindenesetre a Minisztertanács az újabb verziót egy időben jelentette meg a 7 éves terv célszámaival (Pravda, 1958. november 14. és 16., ld. DeWitt, 1961. 14-15. o.), amelyben külön fejezet szólt az oktatási reformról - erről később lesz még szó az SZKP XXI. kongresszusának ismertetésekor.

Ezt követően folytatódott a vita, Laurent Coumel francia történész a törvény ratifikálásáig terjedő időszakot (1958 szeptembere és decembere között) relatív pluralizmusnak nevezi, amikor különböző érdekcsoportok (szülők, pártirányítás, oktatási és gazdasági szakemberek) is kifejthették eltérő véleményüket. Nem véletlen, hogy a korabeli megszólalók gyakran peresztrojkának (átalakításnak) nevezték a reformterveket ${ }^{4}$ - a gorbacsovi időszakot jóval megelőzve. A beszámolók szerint két problémakör alakult ki a reformtervezet országos vitájában: egyrészről kifogásolták, hogy a főiskolai oktatás kezdetére tervezték a gyakorlatot, mert ez veszélyeztette a matematikai-múszaki múveltség megalapozását, másrészt kifogásolták a tehetségeseknek létrehozott külön iskolák ötletét (Szabó, 1958). 1958. december 24-én a Szovjetunió Legfelsőbb Tanácsa törvényerőre emelte a KB és Minisztertanács előterjesztését (az említett problémás részeket kihagyva), ezzel hivatalosan is bevezetésre került az új oktatáspolitika, az iskola és az élet kapcsolatának megerősítéséről szóló szlogennel, és lezárult (egy időre) a viták időszaka.

\section{Az OKTATÁSI TÖRVÉNY}

A törvényszöveg (Az iskola és az élet kapcsolatának megszilárditásáról és a Szovjetunió közoktatási rendszerének továbbfejlesztéséröl. Az elemzés alapjául szolgáló szöveget ld.: Kairov, Goncsarov, Jeszipov és Zankov, 1959. 511-528. o.) bevezetésében a

\footnotetext{
${ }^{4}$ Nikolaj Semenov, Nobel-díjas kémikus például a következő címmel publikált egy cikket 1958 októberében: Megjegyzések a peresztrojka néhány pontjáról (Coumel, 2009. 69. o.).
} 
széleskörú vita, mint legitimációs alap jelent meg, a jogalkotás ezek szerint a dolgozók egyetértésével és jóváhagyásával valósult meg. A régi marxi alapelv a fizikai és szellemi munka újraegyesítéséről újra felbukkant, a jövő társadalmának felépítése csak így volt elképzelhető - Lenint Kairov idézi meg a reform egyik legfőbb hatásaként (1958. 5. o.). Az új embertípus kinevelése lett az iskolák feladata, a kommunista emberben harmonikusan egybeolvad majd a szellemi gazdagság az erkölcsi és fizikai értékekkel. A törvény sajátosan ötvözte a nevelési filozófia értéktételező nyelvezetét a tudományos-technikai terminológiával - az eszménykép felvázolásával párhuzamosan történt meg a népgazdasági érdekek artikulációja.

A termelés gépesítése, az automatizálás, a kemizálás, az elektronika és a villamosítás gyökeresen megváltoztatta a munka jellegét és az ehhez szükséges képzettséget - ez volt a másik fő indoka a változtatásoknak. A termelés bázisán, az állami gazdaságokban és a gyárakban megvalósuló gyakorlati képzés jelenti a fizikai és szellemi munka kettősségének meghaladását - a tudományos-technikai forradalom eredményei azonban nem teszik majd feleslegessé az emberi munkaerőt, csak magasabb szintre emelik annak közremúködését. A gazdasági növekedés eddigi ütemétől azonban elmaradt a szovjet iskolák teljesítménye, így szükségessé vált az iskola közelítése az élethez, azaz a szakember-utánpótlás biztosítása, a fiatalok aktív részvétele a társadalmilag hasznos munkatevékenységben, a kommunizmus felépítésében.

A változtatás, átalakítás valamennyi iskolatípusra kiterjedt. A törvény bevezette a 8 osztályos, nem teljes politechnikai iskolát, ami a termelés tudományos alapjai mellett a munkára nevelés gyakorlatát is tartalmazta. Ezt a 8 évet a munka mellett, immár a termelésben teljesen részt vevő dolgozók számára teljesítették ki: a dolgozók esti iskoláival, a múszaki technikumokkal és a politechnikumi munkaiskolákkal, ${ }^{5}$ - ez utóbbi nem összetévesztendő a 8 évfolyamos politechnikai iskolával! A cél a 15 - 16 éves kort elért diákok bekapcsolása volt a munkába, akik aztán önszorgalmukból, a munka mellett fogják elvégezni a középfokú végzettséghez szükséges három évet. Az eredeti akadémiai elképzelések ugyanezt a 11 évet egy integrált, egységes iskolában képzelték el, ami a fiatalok későbbi belépését jelentette volna a munkaerőpiacra - ezt ellensúlyozta volna a képzés megalapozottabb jellege.

A múszaki szakmai szakképzést és a szakiskolákat külön fejezetekben szerepeltette a jogalkotó, itt az önfenntartást tûzték ki végcélként, amit a termelésben való fokozottabb részvétellel akartak elérni. A tanmúhelyek, üzemi-, kolhoziskolák és egyéb munkaszervezési formák ezért hangsúlyosabban szerepeltek

\footnotetext{
${ }^{5}$ A Szovjetunió iskoláinak többsége eddig 7 osztályos volt, de a nagyvárosokban megvalósultak az eredetileg létrehozni kívánt 10 osztályos intézmények. Az átalakítás mindkét típusra vonatkozott: 8 évfolyamra kellett kiegészíteni, vagy lecsökkenteni a tanintézményeket és ezek mellett létrehozni az esti/levelező intézményeket, technikumokat, vagy új iskolaként, vagy a felsőbb évfolyamokból kialakítva. A középfokú végzettséget a munkás- és parasztifjúság iskoláiban (3 év), nappali középiskolákban (3 év) és technikumokban (3-4 év) lehetett megszerezni (Jóború, 1961. 98. o.).
} 
ezekben a paragrafusokban. A felsőoktatásra szintén vonatkozott az élethez és termeléshez való közelítés igénye: a szakemberképzést jelölte meg a törvény a kibocsátás feltételének, illetve a felvételnél is előnyt élveztek azok, akiknek már volt gyakorlati munkatapasztalatuk. A munka és oktatás világát kölcsönösen közelebb kell hozni egymáshoz, amit elsősorban az esti/levelező képzések kiterjesztésével és a hallgatók gyakorlati munkavégzésével véltek megoldhatónak.

Az átalakításra az 1959/60. tanévtől számítva 3-5 évnyi időtartamot szántak, a törvényre a voluntarista jelleg és az ideológia túlsúlya nyomta rá a bélyegét: az ideális, felépíteni kívánt társadalom képét, és az ehhez szükséges embertípus kinevelésének kérdését tartalmazta a jogszabály, leírta a kommunista ember kívánt személyiségjegyeit, de az új oktatási rendszer felépítésének konkrét megvalósítására, a gyakorlati kérdésekre kevesebb figyelmet fordított. A közösségért élő, a munkát megbecsülő, az építésben aktív szerepet vállaló diák és hallgató képe többféleképpen volt értelmezhető és inkább a nevelésfilozófia, teleológia illetékességi területe volt. A pedagógia sollen jellege (Sáska, 2008) nyomult itt a jog absztrakt területére: az előíró normák azt írták le, hogy milyen legyen az új ember, csakhogy ez alapvetően idegen volt a törvény nyelvétől. A létrejött jogszabály általános kereteket adott, amit sokféleképpen lehetett tartalommal megtölteni és kevéssé lehetett ellenőrizni, hogy mikor, milyen feltételek létrejötte esetén valósulnak meg a célkitúzések. A politikai döntéshozatal folyamata (Hruscsov fellépése -Tézisek - vita és jóváhagyás - törvény) lassan a végéhez közeledett, már csak egy formális, lezáró esemény volt hátra.

\section{Az ÁtAlAKítás LEgITIMÁcióJA: Az SZKP XXI. KONGRESSZUSA (1959. JANUÁR-FEBRUÁR)}

A pártkongresszus a többi szocialista országban, később lezajlott átalakítási folyamatokban is a legitimáló-jóváhagyó szerepet töltötte be. Az SZKP rendkívüli, XXI. kongresszusának jegyzőkönyve (1959. 61-71. 625-626. o.) és az ezt megelőző munkálatok (Hruscsov, 1958c) alapján ismertetem a hétéves terv vonatkozó részét, az oktatási reform gazdasági-politikai hátterét. ${ }^{6}$. Az átalakítás ideológiai megalapozása természetesen Leninre hivatkozott: „minden irányban fejlett és minden irányban iskolázott" emberek nevelése a cél, a továbbiakban a Téziseket ismételte meg az előterjesztés. Az 1959 és 1965 közötti tervidőszakra ütemezte a pártvezetés a nyolc évre felemelt tankötelezettség bevezetését, amihez új tanmúhelyeket kellett biztosítani, a 10 osztályos iskolák (felső osztályok) átszervezéséhez pedig városi, falusi „munkás-középiskolák” hálózatának létrehozása vált szükségessé, illetve a középiskolák számát is bővíteni kellett, hogy be tudják fogadni a munka mellett továbbtanuló diákokat.

\footnotetext{
6 A közoktatási tervezés fogalma ebben az időben honosodott meg az UNESCO regionális konferenciáinak köszönhetően (Temesi, 1962)
} 
Hruscsov kongresszusi előterjesztésében cáfolta azokat a külföldi véleményeket („Hadd károgjanak ezek a jövendőmondók (ti. a nyugati újságírók)..."), melyek szerint a Szovjetuniónak nincs elegendő munkaereje és ezért van szükség a fiatalság bevonására a munkába. ${ }^{7}$ Oktatás és termelőmunka összekapcsolását a távlati tervek aspektusából indokolta meg a főtitkár: a szocializmusból kommunizmusba való átmenet, a kommunizmus anyagi megalapozásának része a reform, a folyamatban Hruscsov külön hangsúlyozta a közösségi nevelés és politechnika erkölcsi aspektusait (a munka szeretete, mint az új szocialista ember típusának meghatározó jellemzője). A kongresszuson elfogadott határozat tartalmazta az intézmények extenzív fejlesztésének számait (például 2300000 szakembert kellett a szovjet főiskoláknak kinevelniük hét év alatt, szemben az előző hét év 1700 000-es adatával), de hasonlóan a korábbi tervezetekhez, nem nagyon körvonalazta a politechnikai oktatás/gyakorlati képzés mibenlétét, technikai részleteit és megvalósítását - ennek feladata a neveléstudományra és a gyakorló pedagógusokra maradt.

A 3 ÉVES ÁLTALÁNOSAN KÉPZÓ ÉS POLITECHNIKAI ISKOLA ÓRATERVE, MELYBEN AZ OKTATAS A TERMELÓ MUNKAVAL OSSZEKAPCSOLVA FOLYIK: (NAPPALI)

\begin{tabular}{|c|c|c|c|}
\hline \multirow{2}{*}{ Tantárgyak } & \multicolumn{3}{|c|}{ Orák száma } \\
\hline & $I X$ & $X$ & $X I$ \\
\hline 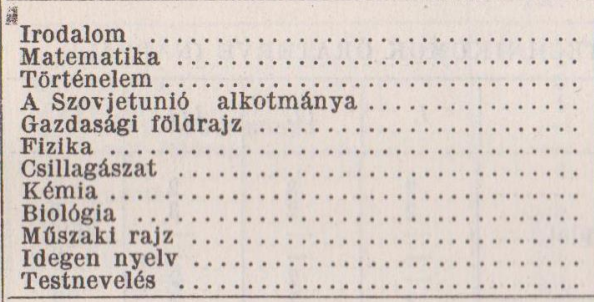 & $\begin{array}{l}3 \\
\frac{4}{2} \\
- \\
4 \\
2 \\
3 \\
2 \\
2 \\
2\end{array}$ & $\begin{array}{l}3 \\
4 \\
3 \\
2 \\
4 \\
1 \\
3 \\
\\
2 \\
2\end{array}$ & $\begin{array}{l}3 \\
4 \\
4 \\
2 \\
2 \\
2 \\
2 \\
\\
3 \\
2\end{array}$ \\
\hline & 24 & 24 & 24 \\
\hline $\begin{array}{c}\text { Altalános technikai tárgyak, termelési oktatás } \\
\text { és termeló munka } \ldots \ldots \ldots \ldots \ldots \ldots \ldots \ldots \ldots\end{array}$ & 12 & 12 & 12 \\
\hline Fakultatív tárgyak $\ldots \ldots \ldots \ldots \ldots \ldots \ldots \ldots$ & $\begin{array}{r}36 \\
2\end{array}$ & $\begin{array}{r}36 \\
2\end{array}$ & $\begin{array}{r}36 \\
2\end{array}$ \\
\hline
\end{tabular}

1. kép

A szovjet középiskola kísérleti óraterve az 1959/60. tanévtől (Jóború, 1961. 99. o.)

Az 1. kép a megvalósulás egy formáját mutatja be, az általánosan képző, politechnikai iskola példáján, ami tulajdonképpen a mi középiskolánknak feleltethető

\footnotetext{
${ }^{7}$ Egy 1958. november 16-án keltezett bizalmas CIA-jelentés szerint (Memorandum. . , 1958) a 7 éves terv 11,5 milliós munkaerő-növekedését a természetes utánpótláson kívül az oktatási reform és a mezőgazdaságból való átirányítás fogja biztosítani a szovjet vezetés számításai szerint.
} 
meg. A legfeltûnőbb a politechnikai tárgyak túlsúlya az óraterhelésben, hiszen az összes óra egyharmadát adja a termeléssel összefüggő elméleti és gyakorlati tárgyak száma - a városi iskolákban ipari, a falusi intézményekben mezőgazdasági jelleggel. Az oktatás és munka váltakozásának rendjét nem határozták meg központilag, így a helyi igényekhez (kolhozokhoz, vállalatokhoz) alkalmazkodva lehetett tanterveket létrehozni. A szakmai képzés színvonala nem érte el a szakmunkás-képzés szintjét, ezért ezt szakmai előképzésnek, vagy általános technikai képzésnek nevezték, szemben a négy éves technikumok magasabb termelési óraszámával és az esti iskolák példájával, ahol a hallgatók már eleve dolgoztak (Jóború, 1961. 99-102. o.). A háromfajta középfokú iskolatípus tehát más-más módon kapcsolta össze az oktatást a termeléssel, ez a fajta differenciálódás az 1961-es magyar iskolareformra is jellemző volt (5+1-es rendszerú gimnázium, szakközépiskola, szakmunkásképző iskola).

\section{BEFEJEZÉS}

Az így létrejövő iskolai szerkezet egyszerre próbált ellentétes irányoknak megfelelni és azokat kibékíteni: a középfokú oktatás expanzióját (pedagógiai-szakmai szempont) a munka melletti képzési formákkal, az eredeti koncepciót redukálva vélték megvalósíthatónak, míg a gazdaságtervezői-politikai oldal által preferált munkaerő-piaci igényeket a gyors munkába állással és a helyi igényeknek megfelelő, praktikus politechnikai készségek elsajátításával, begyakorlásával oldották meg (DeWitt, 1961. 16. o.). A szükségszerú kompromisszum természetesen mindkét irány igényeit sérthette és számos problémát hordozott magában. A helyzet azonban ennél még bonyolultabb volt. Az akadémiai-pedagógiai oldalon belül is voltak ellentétek az átalakítás elkötelezett hívei és az óvatosabb bevezetés hívei között, ${ }^{8}$ továbbá nem szabad elfeledkezni a politika gyakori irányváltásáról, a pártvezetésen belüli harcokról.

Nem véletlen, hogy nemsokára már mentegetőznie kellett Kairovnak (1963) az oktatási reform végrehajtásával kapcsolatban: az általános képzés színvonala nem csökkent, továbbra is nyitva áll a felsőoktatás útja, egyszerre képes a szovjet iskola teljesíteni a szakképzés és a középfokú végzettség kettős feladatát, nem szükséges ehhez az iskolatípusok differenciációja. A meginduló munkálatok elsősorban tantervi-tartalmi kérdéseket érintettek, a túlterhelés csökkentésére irányultak (ld. a Szovjetunióba látogató magyar neveléstudósok beszámolóit: Ábent, 1959; Szoboszlay, 1960), csakhogy a formai javítások, átrendezések nem

\footnotetext{
${ }^{8}$ Arzsanyikov professzor, a múszaki tudományok doktora, a Szovjetunió állami díjait osztó bizottság elnöke (Hírek, 1957) például a „főiskolai gyárak" és „,tanulóüzemek" létrehozása mellett szállt síkra, ahol minimálisra csökkentik az elméletet (Szabó, 1958). Ezzel az álláspontjával szemben állt a felsőoktatás más szereplőinek véleményével, akik az elméleti megalapozást fontosabbnak tartották.
} 
érintették/nem érinthették az alapvetően ambivalens célkitúzéseket, így nem jelentettek megoldást a felmerülő problémákra.

A politechnikai oktatás ekkor kigondolt formája, a munkára nevelés iskolarendszert érintő változásai a hatvanas évek közepére kudarcot vallottak (vagy eufémisztikusabb formában: „„... nem jártak átütő sikerrel”, ld. Köte, 1979. 192) ami döntő módon befolyásolta a reform későbbi megítélését. A sikertelenség okai között volt az anyagi fedezet hiánya, az egymást keresztező, ellentmondásos célok és koncepciók okozta zavar (Kalmár, 2014. 204. o.), továbbá az érintett szereplők (szülők, tanárok, diákok és a munkaerő-piac) egy részének ellenállása - ez azonban már egy másik történet. Nem véletlen, hogy az iskolareformról egy szó sem szerepel Hruscsov terjedelmes önéletrajzában (Crankshaw, 1970, részletek magyarul: Hruscsov, 1990), valamint tanácsadója róla írott könyvében (Burlatsky, 1991). A további kutatásoknak tisztáznia kell a többi szocialista országban végbement változások jellegét, a Szovjetunióval való hasonlóságokat és különbségeket, ami a magyar oktatástörténet jobb megértéséhez is hozzásegíthet minket.

\section{IRODALOM}

Ábent Ferenc (1958a): Az általános és politechnikai képzés tartalmi problémáival foglalkozó értekezlet. Pedagógiai Szemle, 8. 1. szám, 80-83.

Ábent Ferenc (1958b): Új elgondolások az iskolarendszer megreformálására. Pedagógiai Szemle, 8. 12. szám, 1193-1198.

Ábent Ferenc (1959): A szovjet közoktatás átszervezésének néhány tapasztalata. Pedagógiai Szemle, 9. 9. szám, 859-870.

Bori István és Tihanyi Ferenc (1957): A technikai múveltség szerepe néhány nyugati ország iskolarendszerében. Köznevelés, 13. 11-12. szám, 253-255.

Burlatsky, F. (1991): Khruschev and the First Russian Spring. The Era of Khruschev Through the Eyes of His Advisor. Macmillan, New York.

Coumel, L. (2009): The Scientist, the Pedagogue and the Party Official: Interest Groups, Public Opinion and Decision-making in the 1958 Education Reform. In: Ilic, M. és Smith, J. (szerk., 2009): Soviet State and Society under Nikita Khruschev. Routledge, Abingdon - New York, 66-86.

Crankshaw, E. (1970): Khruschev Remembers. Little, Brown and Company, Boston, Toronto.

Csoma Vilmos (1958): A XXI. Nemzetközi Nevelésügyi Konferencia. Köznevelés, 14. 17. szám, 395-397.

DeWitt, N. (1961): Education and Professional Employment in the U.S.S.R. National Science Foundation, Washington.

Faragó László (1957): A politechnikai képzés időszerû feladatai és problémái a szovjet pedagógiában. Köznevelés, 13. 9. szám, 207-209. 
Faragó László (1958): Az OSZSZSZK Neveléstudományi Akadémiájának 1958. évi kutatási terve. Köznevelés, 14. 14. szám, 335-338.

Feljegyzés. Hruscsov elvtárs akadémiai beszédének visszhangja. MNL OL, $288 \mathrm{f}$. 33/1958/3. ő. e. MSZMP KB TKO, Szerényi Sándor, 1958. április 11.

Gorjunov, D. P. (1959): Barátok öröme. Népszabadság, 17. 1959. január 4. 11.

Hírek (1957). Új Szó, 10. 1957. november 10. 2.

Holmes, R, Read, G. H. és Voskresenskaya, N. (1995): Russian Education: Tradition and Transition. Garland Publishing, London - New York.

Hruscsov, Ny. S.z. (1958a): Valamennyi munkás- és kolhozparaszt-fiatal végezze el a középiskolát. Befejeződött a Komszomol XIII. kongresszusa. Népszabadság, 16. 1958. április 20. 6.

Hruscsov, Ny. Sz. (1958b): Feljegyzései a szovjet népoktatás rendszerének fejlesztéséről, az iskola és az élet kapcsolatairól. Népszabadság, 16. 1958. szeptember 23. 6 .

Hruscsov, Ny. Sz. (1958c): A Szovjetunió 1959-1965. évi népgazdaságfejlesztési ellenőrző számai. N. Sz. Hruscsov elvtárs beszámolójának tézisei a Szovjetunió Kommunista Pártja XXI. kongresszusára. Népszabadság, 16. 1958. november 18. 5-8.

Hruscsov, Ny. Sz. (1990): Szemben a zsarnokkal. Hruscsov emlékezik. Leopárd Kiadó, Budapest.

Jóború Magda (1958): A sèvres-i konferenciáról. Pedagógiai Szemle, 8. 7-8. szám, 730-738.

Jóború Magda (1961): Élet és iskola. Gondolat, Budapest.

Kairov, I. A. (1958): Basic Questions Relating to School Reorganization. Soviet Education, 1. 3. szám, 5-12.

Kairov, I. A. (1963): The Reorganization of General Secondary Education. In.: Shapovalenko, S. G. (ed.): Polytechnical Education in the U.S.S.R. UNESCO, Paris-Amsterdam, 55-70.

Kairov, I. A., Goncsarov, N. K., Jeszipov, B. P. és Zankov, L. V. (1959): Pedagógia. Tankönyvkiadó, Budapest.

Kalmár Melinda (2014): Történelmi galaxisok vonzásában. Magyarország és a szovjetrendszer, 1945-1990. Osiris, Budapest.

Kálmán György (1958): A szovjet iskolarendszer reformtervezetéről. Köznevelés, 14. 21. szám, 493-494.

Köte Sándor (1979): A szocialista munkaiskola kezdetei, 1917-1920. Akadémiai Kiadó, Budapest.

Lilge, F. (1959): Impressions of Soviet Education. International Review of Education, 5. 1. szám, 11-27.

Medlin, W. K. (1958): Soviet Pedagogical Academy and the New School Plans. Comparative Education Review, 2. 2. szám, 12-14.

Megkezdődött a vita a Szovjetunióban az iskolarendszer átszervezéséről (1958). Népszabadság, 16. 1958. november 20. 10. 
Memorandum for Director of Central Intelligence: Khruschev's Theses on the SevenYear Economic Plan. (1959-1965). 16, November, 1958. Online: http://www . foia. cia.gov/sites/default/files/document_conversions/89801/D0C_0000234156. pdf, 2015. 04. 27.

Mitter, W. (1981): Das amerikanische und das sowjetische Schulwesen. In: Twellmann, W. (szerk., 1981): Handbuch Schule und Unterricht. Band 3, Pädagogischer Verlag Schwann, Düsseldorf, 521-540.

Nagy Sándor (1958): Iskolarendszertani és didaktikai kutatások a Szovjetunióban. Pedagógiai Szemle, 8. 9. szám, 805-817.

Osztrotyitanov, K. (1958): A kommunizmus építésének elméleti problémái a Szovjetunióban. Népszabadság, 16. 1958. július 5. 2-3.

Ross, L. W. (1960): Some Aspects of Soviet Education. The Journal of Teacher Education,11. 4. szám, 539-552.

Rudman, H. C. (1959): De-emphasis of Academics in the USSR. The Elementary School Journal, 59. 5. szám, 253-257.

Sáska Géza (2008): Régi és új szólamok értelmezése az 1945 utáni pedagógiai kánonban. Új Pedagógiai Szemle, 58. 11-12. szám, 161-187.

Setényi János (1992): Harc a középiskoláért, Kísérletek az egységes középiskola megteremtésére az 1945 utáni Európában. Educatio, Budapest.

Simon György (1960): A tudományos-múszaki forradalom társadalmi következményei. Közgazdasági Szemle, 7. 5. szám, 619-624.

Szabó István (1958): A Szovjetunió Legfelsőbb Tanácsának üléséről. Népszabadság, 16. 1958. december 23. 6.

Szebenyi Péter (1997): Tagoltság és egyesítés - tananyagszabályozás és iskolaszerkezet. Magyar Pedagógia, 97. 3-4. szám, 271-302.

Szkatkin, M. N. (1958): Hogyan fejlődik a politechnikai oktatás elmélete és gyakorlata. Köznevelés, 14. 16. szám, 377-378.

Az SZKP XIX. kongresszusának anyaga (1952), Szikra, Budapest.

Az SZKP XX. kongresszusa (1956), Szikra, Budapest.

Az SZKP XXI. kongresszusa (1959), Kossuth, Budapest.

Az SZKP Központi Bizottságának és a Szovjetunió Minisztertanácsának tézisei az iskola és az élet kapcsolatának erôsítéséről és a szovjet közoktatási rendszer továbbfejlesztéséról. Népszabadság, 16. 1958. november 19. 7.

Szoboszlay Miklós (1960): Az iskolareformmal kapcsolatos tantervi kérdések a Szovjetunióban. Pedagógiai Szemle, 10. 12. szám, 1111-1120.

Szovjetunió. Az elemi, hétéves és középiskola 1957/58. évi kísérleti óraterve (1958). Köznevelés, 14. 4. szám, 92.

Sztálin, I. (1952): A szocializmus közgazdasági problémái a Szovjetunióban. Társadalmi Szemle, 7. 10, 889-946.

Temesi Alfréd (1962): Közoktatási reform és közoktatási tervezés. Pedagógiai Szemle, 12. 9. szám, 798-810.

UNESCO (1958a): Curriculum Revision and Research. UNESCO, Paris. 
Pedagógiatörténeti Szemle • 2. évf. 1-2. sz. 23-39. o. • 2016 DOI:10.22309/PTSZEMLE.2016.1.2

UNESCO (1958b): International Yearbook of Education. Vol. XX. UNESCO, Paris - Geneva.

Zibolen Endre (1958): Iskolarendszeri típusok. Köznevelés, 14. 9. szám, 202-204. 